\title{
GYRODACTYLIDS PARASITIZING SALMONIDS IN BRITTANY AND WESTERN PYRÉNÉES WATER BASINS : EPIDEMIOLOGICAL FEATURES OF INFECTION AND SPECIES COMPOSITION.
}

\author{
A. LAUTRAITE (1), G. BLANC* (2), R. THIERY (3), P. DANIEL (1) \\ and M. VIGNEULLE (3).
}

(1) Groupement de Défense Sanitaire Aquacole d'Aquitaine, 1 rue M. David, BP 219, 40004 MONT-DE-MARSAN Cedex, France.

(2) Laboratoire d'Aquaculture et Pathologie Aquacole, Ecole Nationale Vétérinaire de Nantes, Atlanpole-La Chantrerie, BP 40706, 44307 NANTES Cedex 03, France.

(3) Agence Française de Sécurité Sanitaire des Aliments Brest, Technopôle Brest-Iroise, BP 70, PLOUZANE, F-29280, France.

* Corresponding author.

\begin{abstract}
In the first part of a national survey of gyrodactylid parasites, with special reference to Gyrodactylus salaris, funded by French administrations, two water basins harbouring Atlantic salmon were sampled : Brittany ( 7 rivers and 3 restocking farms) and the Adour basin in the Western Pyrénées (6 rivers and 1 restocking farm). 535 salmonids were collected and examined for $G$. salaris and other gyrodactylid species investigations. Identification procedure was performed by morphological examination and molecular analysis. Both methods led to the same conclusions with a high degree of consistency : Gyrodactylus salaris was declared absent from the examined samples and, therefore, can be considered absent from the sampled water basins with a high level of confidence (over $99.4 \%$ ).
\end{abstract}

A new Gyrodactylus species was identified first by morphological examination and confirmed by molecular analysis. This new species is named Gyrodactylus teuchis (CUNNINGHAM et al., in prep.). This result has been confirmed by an independent study performed in the same time (Dr. C.O. CUNNINGHAM, personal communication). G. teuchis shares several morphological and molecular characters with $G$. salaris. The wrong identification of the latter in France by JOHNSTON et al. (1996) probably originates in their similarities. The absence of Gyrodactylus salaris in both sampled regions, displaying optimal conditions for the parasite's maintenance, leads us to deny its current presence in France. Atlantic salmon parr, mainly parasitized by $G$. derjavini, are not infected by $G$. salaris in Brittany and Western Pyrénées. Rainbow trout and brown trout, for which prevalence of gyrodactylids is significantly higher than on salmon parr, are suitable hosts for $G$. teuchis. This wild fish survey will be extended to other parts of France and probably to farmed salmonids. In the same way, the actual status towards $G$. salaris in whole continental Europe needs to be clarified. Biological characteristics of $G$. teuchis, particularly, its specificity, population dynamics and pathogenesis towards the main host species should be investigated. Besides, further work should be carried out to improve the reliability and efficiency of both identification methods. 


\section{LES GYRODACTYLIDÉS PARASITANT LES SALMONIDÉS DU MASSIF ARMORICAIN ET DES PYRÉNÉES OCCIDENTALES : ASPECTS EPIDÉMIOLOGIQUES DE L'INFECTION ET COMPOSITION SPÉCIFIQUE.}

\section{RÉSUMÉ}

Gyrodactylus salaris est un parasite plathelminthe monogène. Son hôte le plus compatible est le saumon atlantique, mais la truite arc-en-ciel peut aussi héberger ce parasite et permettre le maintien de ses populations. La truite fario, bien que réceptive est un hôte moins compatible pour $G$. salaris. La présence de ce parasite, probablement ancienne dans les bassins versants de la Mer Baltique, passait relativement inaperçue en raison d'une co-évolution avec son hôte, le saumon atlantique du stock balte. Au contraire, son introduction, d'origine anthropique, en Norvège, dans des populations de saumon du stock est-atlantique a provoqué d'importantes mortalités de tacons (plus de $90 \%$ ), dès 1975. Au début des années 80 , les pertes enregistrées mettent en danger la pérennité du saumon atlantique dans certains bassins et ont conduit les administrations norvégiennes à mettre en place un programme d'éradication drastique (empoisonnement des bassins versants à la roténone suivi d'un repeuplement sous contrôle sanitaire renforcé).

La présence de ce parasite en France a été signalée par JOHNSTON et al. en 1996. Devant cette menace potentielle pour les populations sauvages de saumon atlantique français, les autorités du Ministère de l'Environnement et de l'Aménagement du Territoire et celles du Conseil Supérieur de la Pêche ont entrepris une analyse du risque que constitue la présence de ce parasite dans les eaux douces françaises. Dans ce cadre, une enquête épidémiologique a été initiée en 1998 dans les cours d'eau et dans quelques piscicultures de repeuplement, de deux régions hébergeant des stocks naturels numériquement importants de saumons atlantiques : la Bretagne ( 7 rivières et 3 piscicultures) et le bassin de l'Adour ( 6 rivières et une pisciculture) dans les Pyrénées occidentales. Lors de cette étude, 535 salmonidés ont été prélevés par pêche électrique ou récoltés dans les bassins de piscicultures, conditionnés individuellement et examinés pour la recherche de gyrodactyles. Les parasites ont été fixés individuellement entre lame et lamelle pour leur identification morphologique et des nageoires parasitées ont été fixées dans l'éthanol à $70 \%$ pour l'identification par des méthodes moléculaires (restriction enzymatique sur la région ITS des gènes ribosomaux et séquençages des régions $V 4$ et ITS). La cohérence des résultats obtenus par l'emploi conjugué de ces deux méthodes a démontré l'absence de Gyrodactylus salaris dans les prélèvements. Gyrodactylus salaris peut donc être considéré comme absent des deux régions avec un seuil de confiance supérieur à $99,4 \%$.

Une nouvelle espèce appartenant au genre Gyrodactylus a été identifiée par l'examen morphologique puis par l'analyse moléculaire et nommée Gyrodactylus teuchis. Ces résultats ont été confirmés par ceux d'une étude menée indépendamment dans un autre laboratoire (CUNNINGHAM et al., en préparation).

La morphologie de ses sclérites est proche de celle de $G$. salaris. En outre, $G$. teuchis partage avec $G$. salaris la séquence située entre les nucléotides placés en position 679 à 694 de la région V4 ayant servi à l'identification moléculaire de G. salaris en France par JOHNSTON et al. (1996). Ces caractères génétiques sont à l'origine de la confusion entre ces deux espèces. L'absence de $G$. salaris des bassins versants de Bretagne et des Pyrénées occidentales, alors qu'ils présentent les conditions écologiques optimales pour la maintenance des populations de ce parasite, remet en cause le statut sanitaire actuel de la France mentionné dans la réglementation européenne. Les 
populations de tacons, surtout parasitées par G. derjavini, ne sont pas actuellement parasitées par G. salaris, ni en Bretagne ni dans le bassin de l'Adour. La truite arc-en-ciel et la truite fario, chez qui la prévalence des parasites du genre Gyrodactylus est significativement supérieure à celle observée chez le saumon atlantique, sont des hôtes compatibles avec $G$. teuchis.

Une extension de l'étude aux autres bassins versants hébergeant le saumon atlantique en France est en cours de réalisation. Un prolongement de cette enquête aux piscicultures élevant des truites arc-en-ciel serait souhaitable à cause du statut épidémiologique particulier de cette espèce vis-à-vis de $G$. salaris. Plus largement, il apparaît essentiel de clarifier la distribution de $G$. salaris dans les principaux pays producteurs de salmonidés en Europe continentale. Les caractéristiques biologiques, la spécificité d'hôte, la dynamique des populations et la pathogénicité, de G. teuchis devraient être étudiées. Enfin, l'identification spécifique des gyrodactylidés a mis en évidence les limites des méthodes employées et a démontré la nécessité de les améliorer.

\section{INTRODUCTION}

Gyrodactylus salaris (Plathyhelminthe : Monogenea), was first observed in 1952 and described by MALMBERG in 1957 on Atlantic salmon from a Swedish laboratory (MALMBERG, 1993). This parasite was first introduced in Norway in 1975 in the Sunndalsøra farm. Then $G$. salaris spread throughout Norway because of river restocking with infected farmed salmon parrs. The drastic decline, induced by this parasite, among Atlantic salmon parrs (above $90 \%$ mortality in several rivers) and the consecutive decrease in total fishing catches led Nonwegian authorities to apply an eradication programme using rotenone poisonning in the parasitized water basins (JOHNSEN and JENSEN, 1991).

G. salaris has been once reported in France by JOHNSTON et al. (1996). This identification, performed on farmed rainbow trout, was based on both morphological examination and molecular analysis. In order to assess the threat that $G$. salaris represents to the Atlantic salmon populations, French administrations from « Ministère de l'Environnement et de l'Aménagement du Territoire " and from "Conseil Supérieur de la Pêche " funded a gyrodactylids survey programme. This analysis of the risk due to the presumed occurrence of $G$. salaris in France, towards Atlantic salmon populations, included a national survey. This survey was undertaken in 1998 to clarify the distribution of the parasite across the national territory.

Brittany and Western Pyrénées, as the main French water basins harbouring wild Atlantic salmon populations, were first chosen for gyrodactylids investigations with two objectives : (1) approach of some epidemiological features of gyrodactylids infecting salmonid host species ; $(2)$ identification of the sampled Gyrodactylus species occurring in these water basins by morphological examination and molecular analysis.

\section{MATERIALS AND METHODS}

\section{Fish and sampling methods}

In this survey, salmonid samples were collected, by electrofishing (for wild fish) or by netting (for farmed fish), in two French water basins still harbouring large populations of wild Atlantic salmon : Brittany and Western Pyrénées. The sample size reached 30 fish, except in a few localities where the total size is slightly inferior (death of individuals before 
examination). The aimed composition of 20 Atlantic salmon (Salmo salar L.) parr, 10 brown trout (Salmo trutta L.) and, where possible, 10 rainbow trout (Oncorhynchus mykiss W.) for each sample was sometimes impossible to achieve (fishing conditions or absence of one of the target species in the sampled site).

In Brittany, 10 sampling sites were chosen among 7 of the main salmon rivers and 3 restocking farms; in the Western Pyrénées (Adour water basin), 8 sampling sites were selected from the 6 main salmon rivers and one restocking farm was included (Figures 1 and 2). The samples composition, the sampling date and the water temperature in each site are given in Table I.

The fish were individually conditioned and kept alive until examination, in bags filled with local water and inflated with oxygen. They were caught by claw tweezers just behind the head and killed by a section of the brain. Then, the fins were removed and placed in a Petri dish filled with local water. The rest of the body was placed in an examination tank in the same water conditions. The fins (for each fish) and, in several cases, the skin, gills and oral cavity were examined under a stereomicroscope. A fish infected with at least one gyrodactylid was declared positive.

At least one live gyrodactylid was removed from each positive fish, mounted and fixed with ammonium picrate-glycerine in accordance with MALMBERG (1970). The adequate position of each parasite was verified under a $400 \times$ magnification microscope and replaced by an other one when necessary.

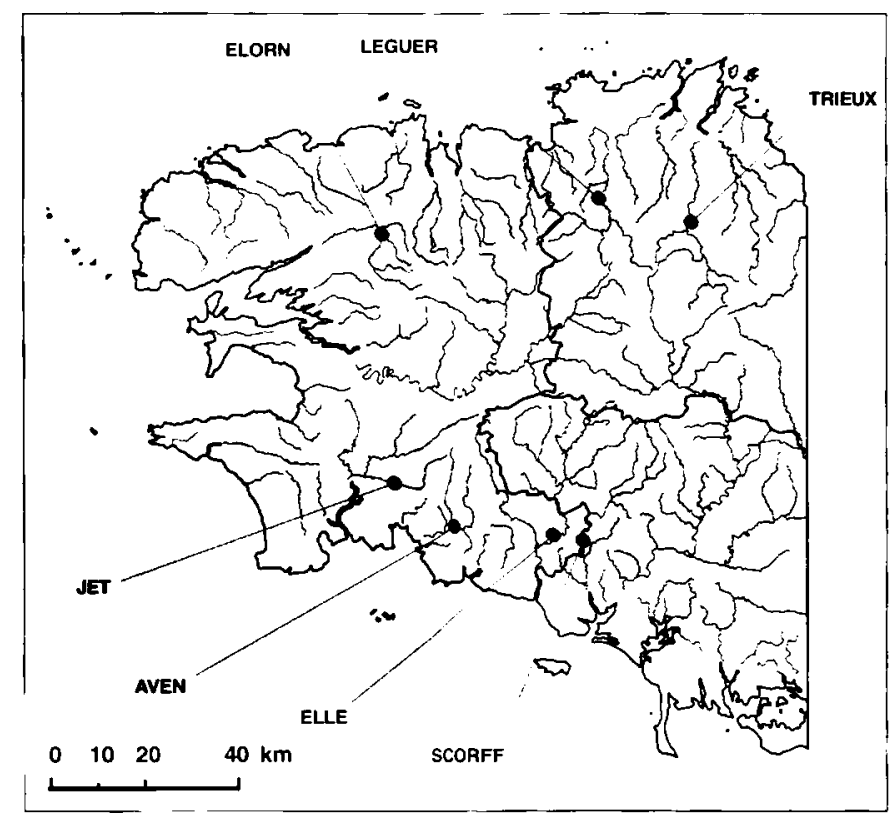

\section{Figure 1}

Geographical distribution of the sampling sites in Brittany. For confidentiality agreements, the farms are not located.

\section{Figure 1}

Répartition géographique des stations en Bretagne. Pour des raisons de confidentialité, les piscicultures ne sont pas localisées. 


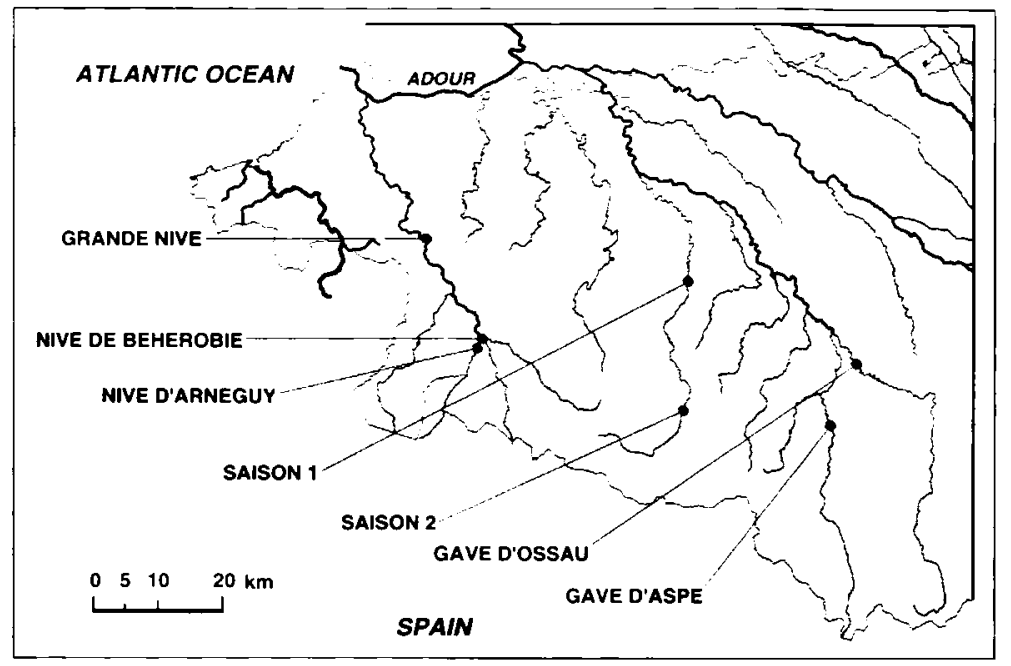

\section{Figure 2}

Geographical distribution of the sampling sites in Western Pyrénées. For confidentiality agreements, the farm is not located.

\section{Figure 2}

Répartition géographique des stations dans les Pyrénées occidentales. Pour des raisons de confidentialité, la pisciculture n'est pas localisée.

\section{Table I}

Sampling date, temperature and sample size for each site.

\section{Tableau 1}

Date de prélèvement, température et taille des échantillons prélevés dans chaque station.

\begin{tabular}{|c|c|c|c|c|c|}
\hline Sampling site & Sampling date & $\begin{array}{c}\text { Temperature } \\
\left({ }^{\circ} \mathrm{C}\right)\end{array}$ & $\begin{array}{c}\text { Total sample } \\
\text { size }\end{array}$ & Host species & $\begin{array}{c}\text { Detailed } \\
\text { sample size }\end{array}$ \\
\hline \multirow{2}{*}{ Nive de Béhérobie } & \multirow{2}{*}{$02 \cdot 10 \cdot 98$} & \multirow{2}{*}{11.8} & \multirow{2}{*}{30} & S. Irutta & 11 \\
\hline & & & & $S$ saler & 19 \\
\hline \multirow{2}{*}{ Nive d'Arnéguy } & \multirow{2}{*}{$07: 10: 98$} & \multirow{2}{*}{11.1} & \multirow{2}{*}{29} & $S$ truttu & 10 \\
\hline & & & & $S$ salar & 19 \\
\hline \multirow{3}{*}{ Grande Nive } & \multirow{3}{*}{$12 \cdot 10 \cdot 98$} & \multirow{3}{*}{133} & \multirow{3}{*}{28} & S rrutia & 17 \\
\hline & & & & S salar & 1 \\
\hline & & & & () mikiss & 10 \\
\hline \multirow{2}{*}{ Gave d'Aspe } & \multirow{2}{*}{161098} & \multirow{2}{*}{9.5} & \multirow{2}{*}{30} & S truttus & 27 \\
\hline & & & & S salur & 3 \\
\hline \multirow{2}{*}{ Gave d'Ossall } & \multirow{2}{*}{201098} & \multirow{2}{*}{8.5} & \multirow{2}{*}{30} & $S$ trutsis & 8 \\
\hline & & & & $S$ sular & $\overline{22}$ \\
\hline \multirow{2}{*}{ Saison 1} & \multirow{2}{*}{231098} & \multirow{2}{*}{12.9} & \multirow{2}{*}{30} & Strutud & 0 \\
\hline & & & & S sulur & 30 \\
\hline \multirow{2}{*}{ Saison 2} & \multirow{2}{*}{261098} & \multirow{2}{*}{9.9} & \multirow{2}{*}{29} & S trutu & 28 \\
\hline & & & & 5 salar & 1 \\
\hline \multirow{2}{*}{ Elorn } & \multirow{2}{*}{231198} & \multirow{2}{*}{7.0} & 30 & S. trutua & 10 \\
\hline & & & 90 & S. sular & 20 \\
\hline Seorff & 351198 & 60 & 30 & S.trutts & 10 \\
\hline Scoril & 2.1198 & 0.0 & 20 & S salar & 20 \\
\hline Léguer & & & & S. truta & 10 \\
\hline Léguer & 27.1198 & 90 & 30 & S sulur & 20 \\
\hline Fille & 301198 & 70 & 30 & S rutua & 16 \\
\hline ne & & & & $S$ salur & 14 \\
\hline & & & & S truts & 10 \\
\hline Trieux & 021298 & 6.0 & 29 & S salur & 19 \\
\hline Aven & 041298 & 65 & 30 & S truta & 8 \\
\hline Aven & $041-98$ & 0.3 & 30 & S salur & 22 \\
\hline Jet & 071298 & 75 & 30 & $S$ rruta & 13 \\
\hline & & & 20 & S sular & 17 \\
\hline
\end{tabular}


Parasitized fins from Brittany samples were fixed in $70 \%$ ethanol and were used for molecular investigations.

\section{Prevalence}

The use of ecological terms follows MARGOLIS et al. (1982). $95 \%$ confidence intervals were calculated in accordance with THRUSFIELD (1995). Groups of results have been tested for significant $(p<0.05)$ to very highly significant $(p<0.001)$ differences by $\chi^{2}$ test for large samples or by Fisher's exact test for small samples according to THRUSFIELD (1995).

\section{Morphological identification}

The gyrodactylid species were identified according to MALMBERG (1970) and O.I.E. "Diagnostic manual for aquatic animal disease » by microscopic examination and drawing of the sclerites in phase contrast light microscopy (Leitz-Laborlux $S$ ) equipped with a drawing tube (Leitz).

Drawings were performed for : (1) measurement of 14 morphometric characters on each parasite and comparisons with those recorded on Gyrodactylus salaris in the O.I.E. manual ; a precise measurement of one or several characters was, in a few cases, rendered difficult when sclerites position was inadequate or when parasite preparation had occasioned partial damages ; (2) morphological comparisons (at the same scale) between the sclerites and different reference drawings from the literature (MALMBERG, 1970 ; ERGENS, 1981 ; MO, 1991a, b and c ; PROST, 1991 ; ERGENS, 1992a, b ; MALMBERG, 1993 ; SHINN, SOMMERVILLE and GIBSON, 1995 ; O.I.E., 1997) or from drawings of mounted parasites kindly provided by Dr T.A. MO.

\section{Molecular analysis}

\section{Lysis}

Fixed fins were removed from $70 \%$ ethanol, placed in a Petri dish filled with distilled water and examined under a $20 \times$ magnification stereomicroscope. Each gyrodactylid was picked from the surface of the fin, placed in a $1.5 \mathrm{ml}$ microtube containing $10 \mu$ lysis solution (TE Buffer, $1 \mathrm{X}$; proteinase $\mathrm{K}, 100 \mu \mathrm{g} / \mathrm{ml}$; IGEPAL CA-360, 0.45 \% ; TWEEN 20, $0.45 \%$ ), incubated 20 minutes at $65^{\circ} \mathrm{C}$. Then this mixture was heated 10 minutes at $95^{\circ} \mathrm{C}$ to denaturate the proteinase $\mathrm{K}$. This method was adapted from CUNNINGHAM et al. (1995).

\section{Primers and PCR conditions}

Aliquots of the lysate $(2.5 \mu \mathrm{l})$ were used as template in different amplification reactions of two distinct regions of the ribosomal gene cluster : (1) V4 region coding for the $18 \mathrm{~S}$ ribosomal RNA; (2) ITS region including internal transcribed spacers and ribosomal RNA $5.8 \mathrm{~S}$ (Figure 3).

Amplification of ITS region was adapted from CUNNINGHAM (1997). The total mixture volume of $45 \mu$ included : buffer $1 \times$ (Perkin Elmer); $\mathrm{MgCl}_{2}, 1.5 \mathrm{mM}$ (Perkin Elmer) ; dNTP, $200 \mu \mathrm{M}$ each (Boehringer-Mannheim) ; primers (ITS1 and ITS2, Genset), $1 \mu \mathrm{M}$ each ; template, $2.5 \mu \mathrm{l} ; \mathrm{HO}$. The mixture was heated to $95^{\circ} \mathrm{C}$ for 5 minutes, then $5 \mu \mathrm{H}_{2} \mathrm{O}$ containing $2.5 \mathrm{U}$ Taq polymerase (Ampli Taq, Perkin Elmer) were added to realise a hot start, giving a total reaction volume of $50 \mu \mathrm{l}$. This mixture was then submitted to 30 cycles $\left(94^{\circ} \mathrm{C}, 1 \mathrm{~min} ; 50^{\circ} \mathrm{C}, 1 \mathrm{~min} ; 72^{\circ} \mathrm{C}, 2 \mathrm{~min}\right)$ ended by a final step at $72^{\circ} \mathrm{C}, 10 \mathrm{~min}$. All steps were performed in a "Gene Amp PCR System 9600, Perkin Elmer ". 

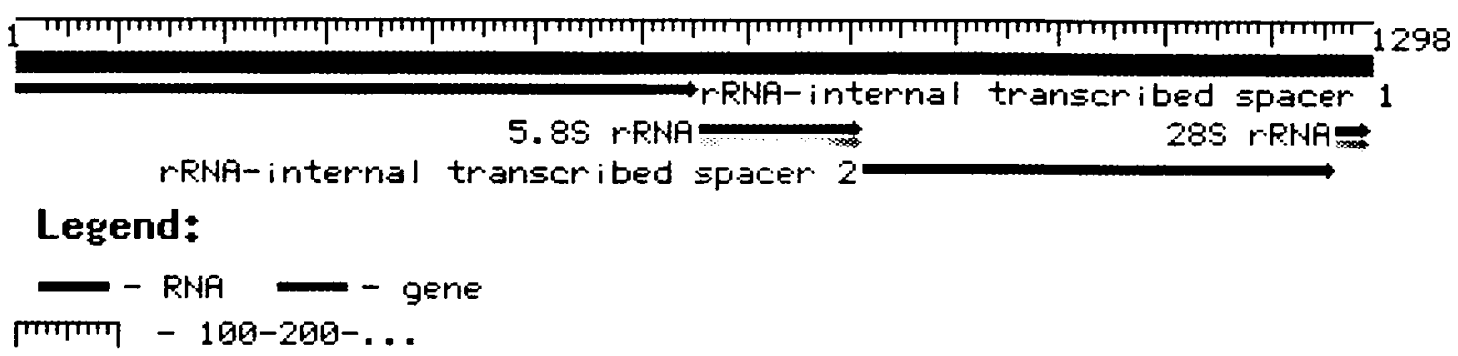

\section{Figure 3}

(from GeneBank) Schematic diagram of Gyrodactylus salaris ITS region.

\section{Figure 3 \\ (d'après GeneBank) Représentation linéaire schématique de la région ITS de Gyrodactylus salaris.}

Amplification of V4 region, adapted from that of CUNNINGHAM et al. (1995), was identical to the amplification of ITS, except primers, V4F and V4R (instead of ITS1 and ITS2) and $\mathrm{MgCl}_{2}, 2 \mathrm{mM}$ (instead of $1.5 \mathrm{mM}$ ).

\section{Sequencing and sequence analysis}

ITS or V4 amplification products were purified with " high pure PCR products purification kit (Boehringer-Mannheim) " and directly sequenced using an automated sequencer " $373 \mathrm{~A}$, Applied Biosystems" and the "ABI prism sequencing kit (Perkin Elmer) ".

ITS restriction enzyme cut sites and restriction fragment sizes were predicted using "DNAsis v2.5 (Itachi Software) ". Multiple alignment of V4 sequences were performed using the same software.

\section{Plasmids}

Clones of Escherichia coli containing plasmids with the ITS region of Gyrodactylus derjavini, G. salaris and G. truttae were kindly provided by $\operatorname{Dr}$ C.O. CUNNINGHAM (Marlab, Aberdeen). The plasmids were used as template in different amplifications.

\section{Restriction analysis of the ITS region}

ITS amplification products were digested with enzymes Sau $3 \mathrm{Al}$ and Hae III (CUNNINGHAM, 1997), and subjected to electrophoresis in a $1.5 \%(\mathrm{w} / \mathrm{v})$ agarose gel. The patterns of $G$. salaris are shown in Figure 4. The amplification products from purified plasmids were used as controls for the restriction patterns of $G$. derjavini, $G$. salaris and G. truttae. For each gyrodactylid specimen, restrictions with Sau $3 \mathrm{Al}$ and Hae III were performed on an equal volume of ITS amplification products. 


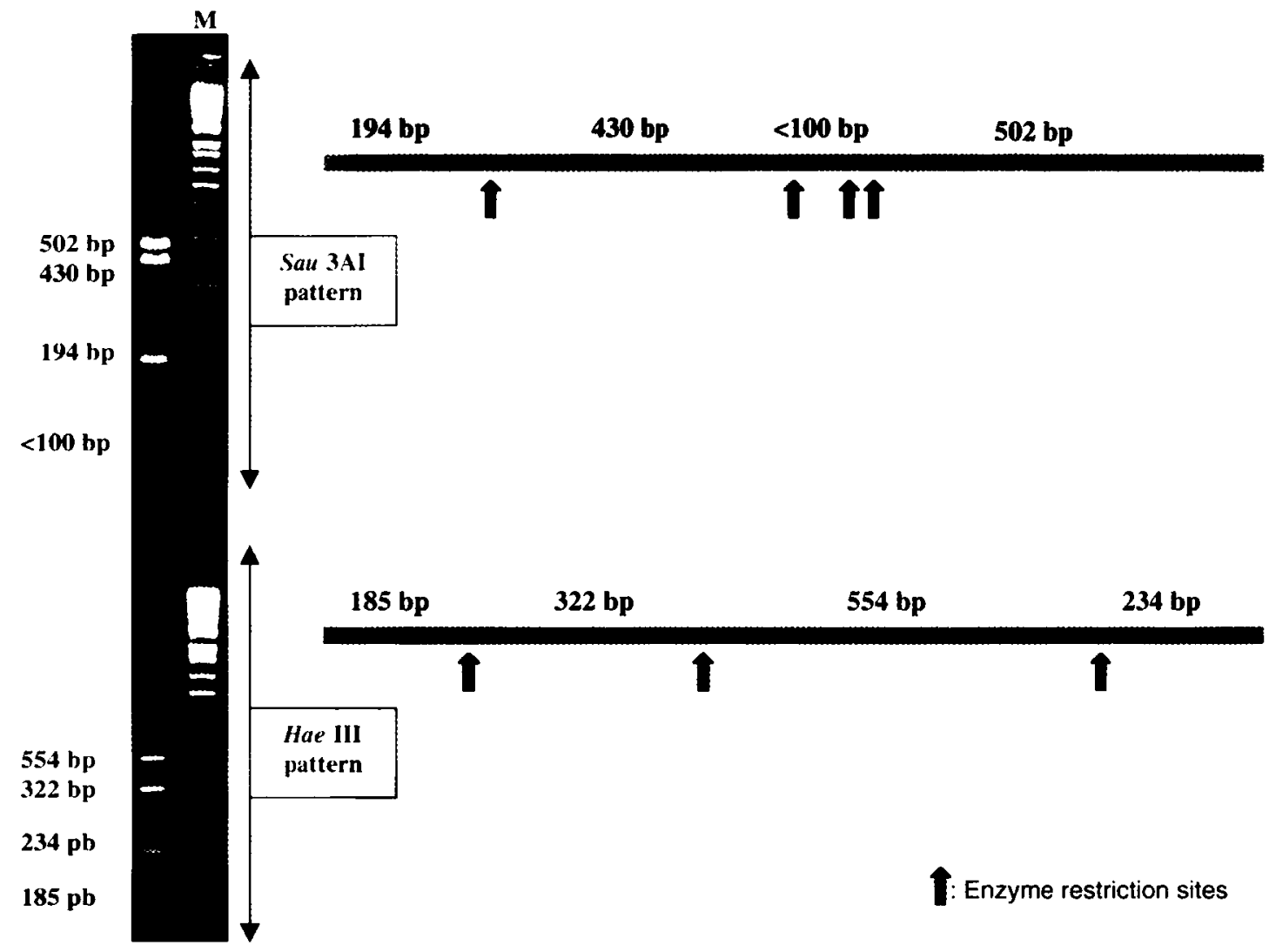

Figure 4

Theoretical restriction patterns compared with observed restriction patterns from Gyrodactylus salaris. M : DNA size marker (Raoul, Appligene oncor) ; bp : base pairs.

Figure 4

Profils de restriction enzymatique théoriques et profils correspondants observés chez Gyrodactylus salaris. M : marqueur de poids moléculaire (Raoul, Appligene oncor) ; bp : paires de bases.

\section{RESULTS}

\section{Epidemiological features in gyrodactylid infections}

A total of 535 fish composed of the major salmonid species (307 Atlantic salmon parr measuring 5 to $22 \mathrm{~cm} ; 218$ brown trout measuring 5 to $31 \mathrm{~cm}$ and 10 rainbow trout measuring 27 to $31 \mathrm{~cm}$ ) in the investigated water basins were sampled. The examination of these fish for the presence of gyrodactylids led to the following results (see also Figure 5) :

(1) the prevalence of gyrodactylid parasites among brown trout is significantly higher $\left(\chi^{2}{ }_{\text {1af }}=20.67 ; p<0.001\right)$ in Brittany than in Western Pyrénées, the same result is also observed on salmon parr $\left(\chi^{2}{ }_{\text {att }}=3.97 ; p<0.05\right)$;

(2) the prevalence of gyrodactylids among brown trout is significantly higher on farmed fish than on wild fish $\left(\chi^{2}{ }_{1 \mathrm{ft}}=8.28 ; p<0.005\right)$. On the contrary, gyrodactylid prevalence among farmed salmon parr is significantly lower than among wild salmon $\left(\chi^{2}{ }_{19 t}=37.62 ; p<0.001\right)$; 
(3) the prevalence of gyrodactylids among wild brown trout is significantly higher than among wild salmon parr (Western Pyrénées : $\chi^{2}{ }_{1 \mathrm{tt}}=5.66, p<0.05$; Brittany : $\left.\chi^{2}{ }_{10 t}=44.68, p<0.001\right)$. This difference is amplified in restocking farms $\left(\chi^{2}{ }_{10 t}=99.59\right.$; $p<0.001)$. In the Western Pyrénées, prevalence of gyrodactylids among rainbow trout is significantly higher than among wild salmon parr $(p<0.01$; Fisher's exact test) while there is no significant difference between rainbow trout and wild brown trout prevalences.

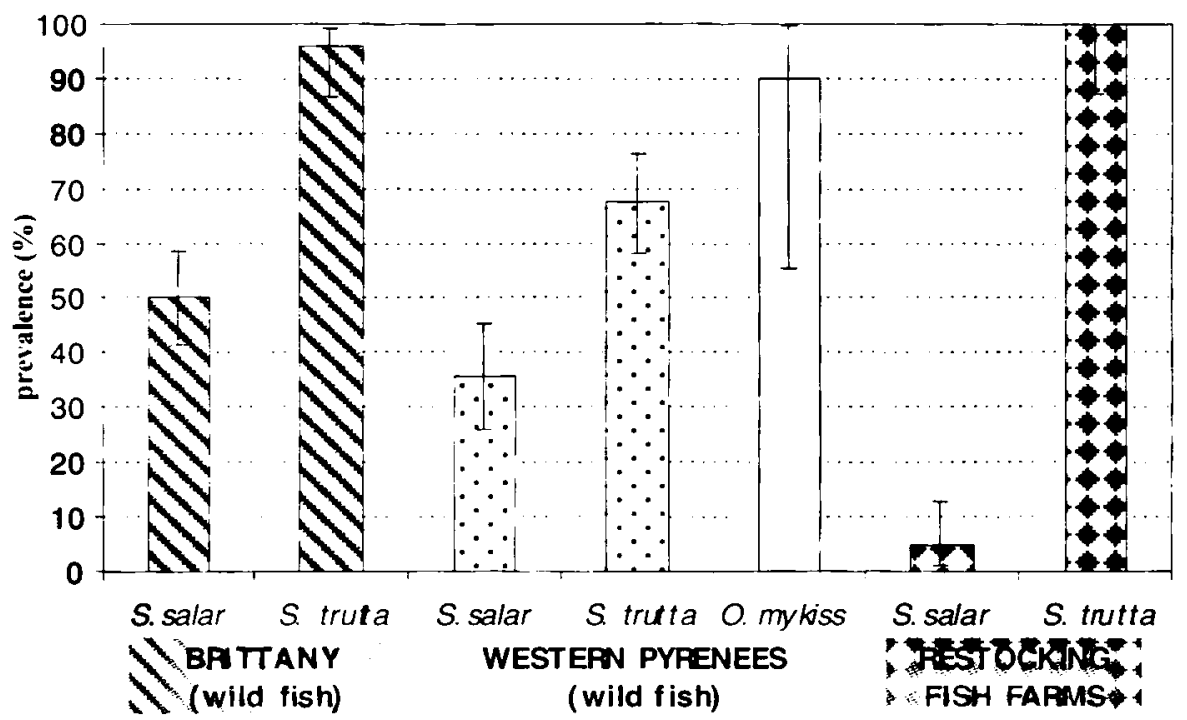

Figure 5

Prevalence per host species, region and environment.

\section{Figure 5}

Prévalence par espèce hôte, par région et par milieu.

\section{Gyrodactylids morphological identification}

91 specimens from the fins and the body of brown trout, 20 specimens from the fins of Atlantic salmon and 10 specimens from the fins and the body of rainbow trout were collected during this study and were examined for morphological characters, measurements and microscopic identification. All these specimens were alive when prepared individually according to the ammonium picrate glycerine method (MALMBERG, 1970). The point to point morphometrics and the descriptive terminology were in accordance with MALMBERG, 1970.

Two gyrodactylid species were identified in the samples: Gyrodactylus deriavini and G. truttae. Beside these species, an undescribed morphotype $X$ occurred on any investigated salmonid host. The drawings of the opisthaptoral sclerites and the cirrus (Figure 6) are from one morphotype $X$ specimen which is in the second author's collection $\left(n^{\circ}\right.$ 1999.150.ENVN).

Body shape and characters typical for the genus Gyrodactylus Nordmann, 1832. Cirrus $24 \mu \mathrm{m}$ in its largest diameter, armed with a single row of inequal spines. One large spine and 7 smaller spines of different sizes (Figure 6). Pharyngeal processes long. Opisthaptor sub-ovate, distinctly demarcated from the body. The morphological characteristics of the opisthaptoral hard parts are given in Figure 6 ; the measurements of 
the sclerites are presented in Table II. Ventral bar is characterized by constant and short lateral processes and a tongue-shaped long membrane. Dorsal bar almost straight, tapering towards anchor attachements (Figure 6). Marginal hook sickle with point and shaft slendering throughout their lengths, the point tapering well beyond the toe. The toe is mostly triangular in shape, and drops below the attachement of the sickle with the marginal hook shaft. Marginal hook handle most narrow at sickle attachement point and gradually wider in its proximal end (Figure 6). In conclusion, all these morphological characters were consistent for the specimens presented in this paper. It is believed that these morphological characteristics represent an undescribded species of Gyrodactylus. On the basis of these results, molecular analysis of this species were then undertaken.

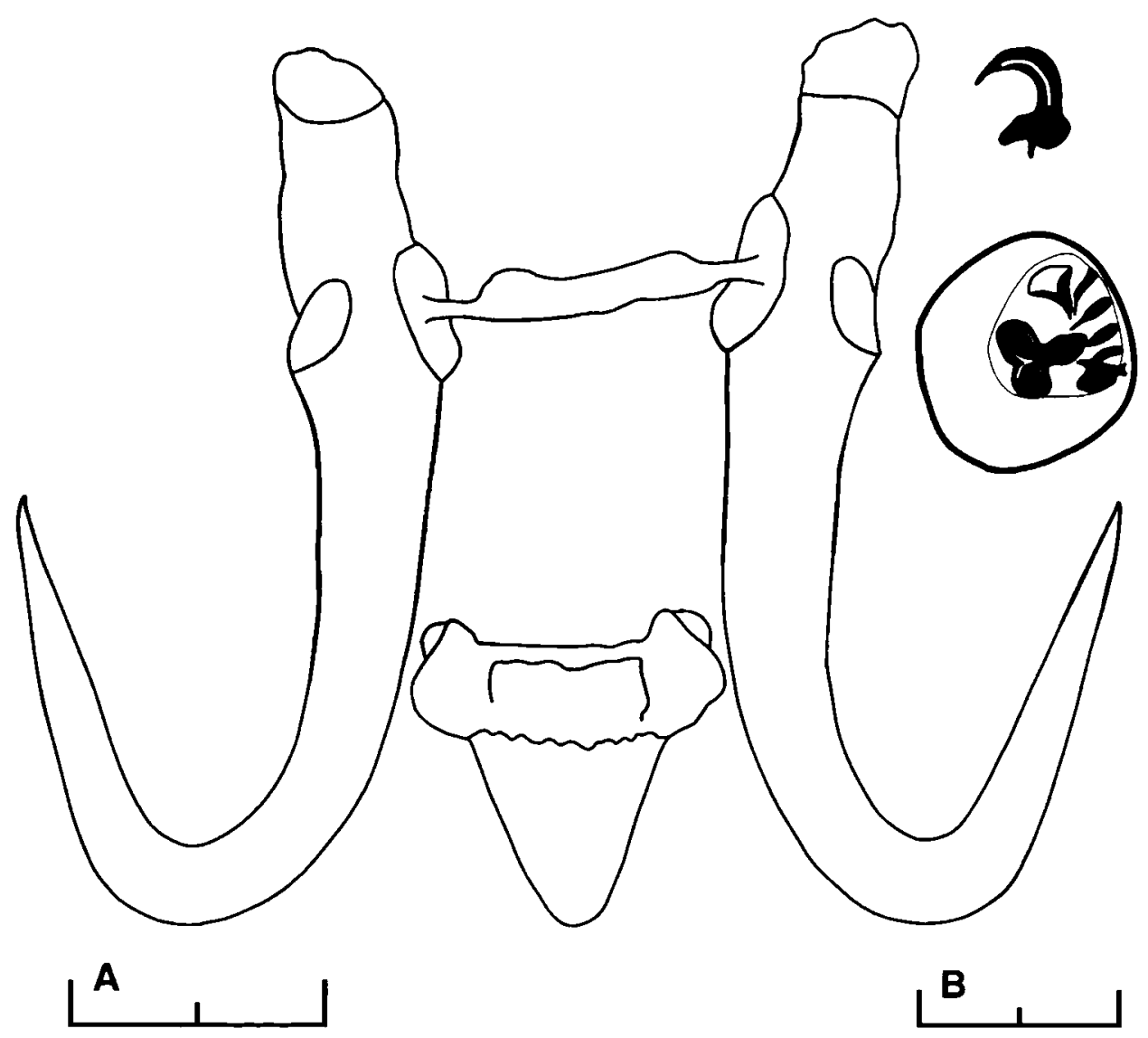

Figure 6

The opistohaptoral hard parts and cirrus of Gyrodactylus teuchis from Salmo trutta fario $L$. Scale bars (1 division $=10 \mu \mathrm{m}): A=$ anchors, cirrus and marginal hooks sickle ; $B$ = ventral bar.

\section{Figure 6}

Parties dures de l'opisthapteur et cirre de Gyrodactylus teuchis parasitant Salmo trutta fario $\mathrm{L}$. Echelles (1 division $=10 \mu \mathrm{m}$ ) : A = ancres, barre dorsale et faucille du crochet marginal ; $B=$ barre ventrale. 


\section{Table II}

Dimensions in 14 characters measured on marginal hooks, anchors and ventral bars of 91 specimens of Gyrodactylus morphotype $X$ on brown trout collected in Brittany and Western Pyrénées. The water temperature varied between $6^{\circ}$ to $15^{\circ} \mathrm{C}$ (mean $\pm \mathrm{SD}: 8.6 \pm 1.9^{\circ} \mathrm{C}$ ). All measurements are in micrometres. $\mathrm{NM}=$ number of measurements.

\section{Tableau II}

Dimensions de 14 caractères mesurés sur les crochets marginaux, les ancres et les barres ventrales de 91 spécimens de Gyrodactylus morphotype X collectés chez la truite fario en Bretagne et dans les Pyrénées occidentales. La température se situait entre 6 et $15^{\circ} \mathrm{C}$ (moyenne \pm écart-type :8,6 $\pm 1,9^{\circ} \mathrm{C}$ ). Toutes les mesures sont données en micromètres. $N M=$ nombre de mesures.

\begin{tabular}{|c|c|c|c|}
\hline Character measured & NM & Mean \pm SD & Range of variation \\
\hline Total length of marginal hook (Imh) & 91 & $36.4 \pm 1.0$ & $33.5-39.3$ \\
\hline Length of marginal hook handle (lh) & 91 & $29.3 \pm 0.9$ & $26.7-32.2$ \\
\hline Length of marginal hook sickle (Isi) & 91 & $8.2 \pm 0.4$ & $7.1-9.3$ \\
\hline Total length of anchor (la) & 91 & $69.0 \pm 2.2$ & $60.5-74.2$ \\
\hline Length of anchor shaft (las) & 91 & $52.2 \pm 1.8$ & $43.6-56.2$ \\
\hline Length of anchor point (lap) & 91 & $35.3 \pm 1.3$ & $31.1-40.9$ \\
\hline Length of anchor root (lar) & 91 & $22.9 \pm 1.6$ & $17.4-27.0$ \\
\hline $\begin{array}{l}\text { Maximal distance between processus of } \\
\text { ventral bar (mdpvb) }\end{array}$ & 89 & $28.4 \pm 1.4$ & $22.1-32.7$ \\
\hline Length of ventral bar (lvb) & 90 & $29.8 \pm 1.0$ & $25.9-31.9$ \\
\hline Total basal width of ventral bar (tbwvb) & 86 & $30.0 \pm 1.7$ & $26.2-34.9$ \\
\hline Basal width of ventral bar (bwvb) & 87 & $12.5 \pm 0.9$ & $9.8-15.8$ \\
\hline Total median width of ventral bar (tmwvb) & 86 & $25.9 \pm 1.6$ & $22.9 \cdot 30.3$ \\
\hline Length of ventral bar membrane (lvbm) & 84 & $17.0 \pm 1.6$ & $13.9-21.8$ \\
\hline Median width of ventral bar (mwvb) & 86 & $8.9 \pm 0.9$ & $7.1-11.4$ \\
\hline
\end{tabular}

\section{Gyrodactylids molecular analysis}

DNA amplification of ITS region was performed on 92 gyrodactylid specimens picked from ethanol preserved fins, from fish sampled in Brittany ( 18 wild brown trout, 2 farmed brown trout and 1 wild Atlantic salmon).

Digestion of the ITS amplification products from the 92 specimens with Sau 3AI only revealed patterns of Gyrodactylus derjavini as shown in Figure 7a. No other pattern, nor $G$. salaris pattern were ever observed in the Sau 3AI digestions.

Digestion with Hae III, performed on 86 specimens (also digested with Sau 3AI), produced restriction fragment length polymorphism, with two different patterns (shown in Figure $7 \mathrm{~b}$ ) : (1) $G$. derjavini pattern was observed in 31 cases ; (2) an original pattern was observed in 55 gyrodactylids. The latter differs from those of $G$. derjavini, G. salaris and $G$. truttae as seen from the control plasmid amplification products.

This original pattern was also recently observed by C.O. CUNNINGHAM (personal communication). 


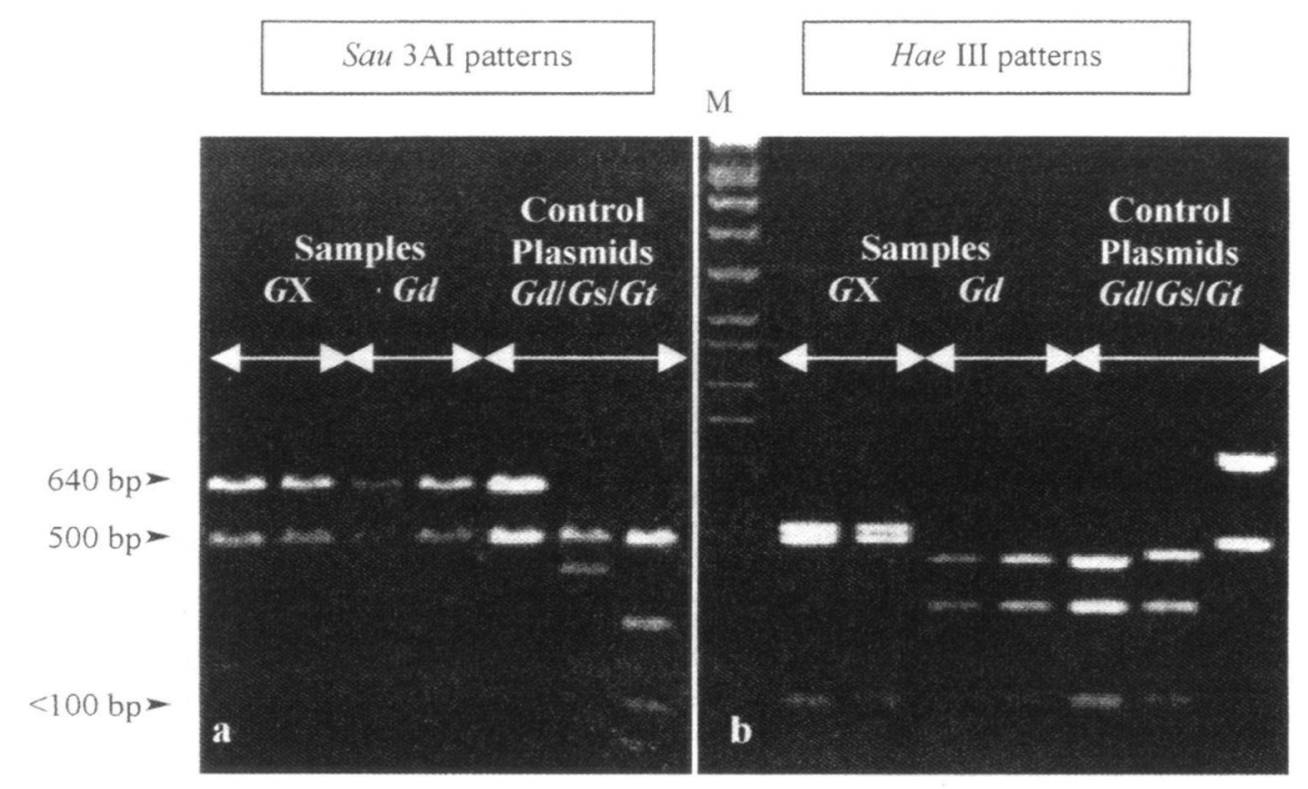

\section{Figure 7}

Enzyme digestion by Sau $3 \mathrm{Al}$ (a) and Hae III (b) : morphotype $X(G \times)$ and G. derjavini $(G d)$ patterns from Brittany samples compared with control patterns from G. derjavini $(G d)$, G. salaris (Gs) and $G$. truttae (Gt) plasmids. M : DNA size marker (Raoul, Appligene oncor).

\section{Figure 7}

Digestion par les enzymes Sau 3Al (a) et Hae III (b) : Profils du morphotype X $(G X)$ et de $G$. derjavini $(G d)$ obtenus à partir d'échantillons bretons comparés aux profils témoins de $G$. derjavini $(G d)$, G. salaris $(G s)$ et $G$. truttae (Gt) obtenus à partir de plasmides. $M$ : marqueur de poids moléculaire (Raoul, Appligene oncor).

In a farm, 21 gyrodactylids were randomly sampled (one parasite per fish) from 21 brown trout. Their morphological examination led to the exclusive identification of morphotype X. ITS digestion analysis of 6 other gyrodactylids from the same farm revealed only the new pattern. Thus, the sampled gyrodactylids from this farm all belong to the morphotype $X$ or display the new molecular pattern. Because of its exclusive association with the morphotype $X$, the new ITS pattern was also named $X$. Two gyrodactylids with $X$ pattern, picked from a single farmed brown trout, were used for ITS and V4 sequencing.

The differences between V4 sequences of $G$. derjavini, $G$. salaris, $G$. truttae (available in EMBL data bank) and that from the new $X$ pattern are shown in the multiple alignment of their respective sequences (Figure 8 ). These differences demonstrate the originality of the genotype $X$. The same conclusions are obtained from the multiple alignment of ITS sequences (not shown in this paper).

In the ITS digestion products by Hae III, three different bands were observed. Their estimated lengths were around 580,550 and 230 bases pairs. These restriction fragment lengths were confirmed by theoretical patterns predicted from the $X$ ITS sequence. 

G. DERJAVINI
G. TRUTTAE
G. SALARIS
G. $X$
G. DERJAVINI
G. TRUTTAE
G. SALARIS
G. $\mathrm{X}$
G. DERJAVINI
G. TRUTTAE
G. SALARIS
G. $X$
G. DERJAVINI
G. TRUTTAE
G. SALARIS
G. $X$
G. DERJAVINI
G. TRUTTAE
G. SALARIS
G. $X$

\begin{tabular}{|c|c|c|c|c|c|c|}
\hline & $--\mathrm{T}$ & CT & CCTTAGT & छTTTT & CATGAAGCTT & \\
\hline & $------\mathrm{T}$ & ACTGCT & TGTTCATAGT & GGATTGTTTT & CATGAAGCTT & \\
\hline 51 & GTTCTGGTTT & GGAGACTGCT & TGCTCTTAGT & GAATTGATTT & CATGAAGCTT & \\
\hline 51 & GTTCTGGTTT & GGAGACTGCT & TGCTCTTAGT & GAATTGATTT & CATGAAGCTT & \\
\hline & & 710 & 720 & 730 & 740 & \\
\hline & TGGGCAGCGG & ETAGG & TCTTC & CAGC & TGCA & \\
\hline & TGGGCAGCGG & TACTTCTAGG & CCGAATCTTC & TGTGTC & TGCATAAGGC & \\
\hline & TGGGCAGCGG & TCTAGG & АТСтTC & GTC & GGC & \\
\hline & TGGGCAGCGG & $\begin{array}{l}\text { TACTTCTAGG } \\
760\end{array}$ & $\begin{array}{l}\text { CCGAATCTTC } \\
770\end{array}$ & $\begin{array}{l}\text { CAGCTGTGTC } \\
780\end{array}$ & $\begin{array}{l}\text { TGCATAAGGC } \\
790\end{array}$ & \\
\hline & TG & TGTAGATAGA & TTCGTTGTAT & $\mathrm{CCC}$ & TCACGGGTCT & \\
\hline & TTCGGCTTTG & AGA & TGTGT & $\operatorname{Tccc}$ & TCT & \\
\hline & TTCGGCTTTG & ATAGA & TTGTAT & ¿TTCCC & TCACGGGTCT & \\
\hline & TTCGGCTTTG & $\begin{array}{l}\text { TGTAGATAGA } \\
810\end{array}$ & $\begin{array}{l}\text { TTCGTTGTGT } \\
820\end{array}$ & $\begin{array}{l}\text { GTAAGTTCCC } \\
830\end{array}$ & $\begin{array}{l}\text { TCACGGGTCT } \\
840\end{array}$ & \\
\hline & CTTCTTCGT & TTCTATACGC & TGTAATGCCT & TTAA & GTTCA & \\
\hline & TCGG & & CT & GT & GTG & \\
\hline & ACTTCTTCGT & $\operatorname{ACGC}$ & ATGCCT & GGGT & GTTCAGTGTG & \\
\hline & TCACCTTCGT & $\begin{array}{l}\text { TTCTATACGC } \\
860\end{array}$ & $\begin{array}{l}\text { TGTAATGCCT } \\
870\end{array}$ & $\begin{array}{l}\text { TTAATCGGGT } \\
880\end{array}$ & $\begin{array}{l}\text { GTTCAGTGTG } \\
890\end{array}$ & \\
\hline & CGT & & & & & \\
\hline & & & & & & \\
\hline & GACAGCACGT & TTGAA & CAAATTT & TG & $A G$ & \\
\hline & GACAGCACGT & TTACTTTGAA & CAAATI & TGCTCAA & & \\
\hline
\end{tabular}

Figure 8

Multiple alignments of V4 region from G. derjavini, G. salaris, G. truttae and morphotype $X(G X)$. Framed portion : target sequence for probe GsV4B hybridization (nucleotides 679-694) used in previous identification of $G$. salaris (CUNNIGHAM et al., 1995).

\section{Figure 8}

Alignements multiples sur la région V4 de G. derjavini, G. salaris, G. truttae (Gt) et du morphotype $X(G X)$. Encadré : séquence cible de la sonde oligonucléotidique GsV4B (nucléotides 679-694) pour l'identification de G. salaris par hybridation (CUNNIGHAM et al., 1995).

\section{Table III}

Degrees of homology between the different sequences of 18 S rRNA V4 region.

\section{Tableau III}

Pourcentages d'homologie entre les différentes séquences de la région V4 de I'ARN ribosomal $18 \mathrm{~S}$.

\begin{tabular}{|c|c|c|c|}
\hline species & G. derjavini & G. truttae & $G . \mathrm{X}$ \\
\hline$G$. salaris & $97.5 \%$ & $93.0 \%$ & $96.5 \%$ \\
\hline \multirow{2}{*}{$G$. derjavini } & $92.5 \%$ & $94.5 \%$ \\
\cline { 2 - 4 } & & G. truttae & $95.0 \%$ \\
\cline { 2 - 4 }
\end{tabular}

The XV4 sequence presents some homology with the three others (see Table III). It must be highlighted that Gyrodactylus salaris and the new sequence share some identical parts, especially from positions 679 to 694 (framed portions, Figure 8). This particular sequence was used for identification of Gyrodactylus salaris by probe hybridization (CUNNINGHAM et al., 1995). This molecular method was used to ascertain the morphological identification of $G$. salaris in France (JOHNSTON et al., 1996). However, such a method is unable to distinguish Gyrodactylus salaris from the morphotype $\mathrm{X}$. 


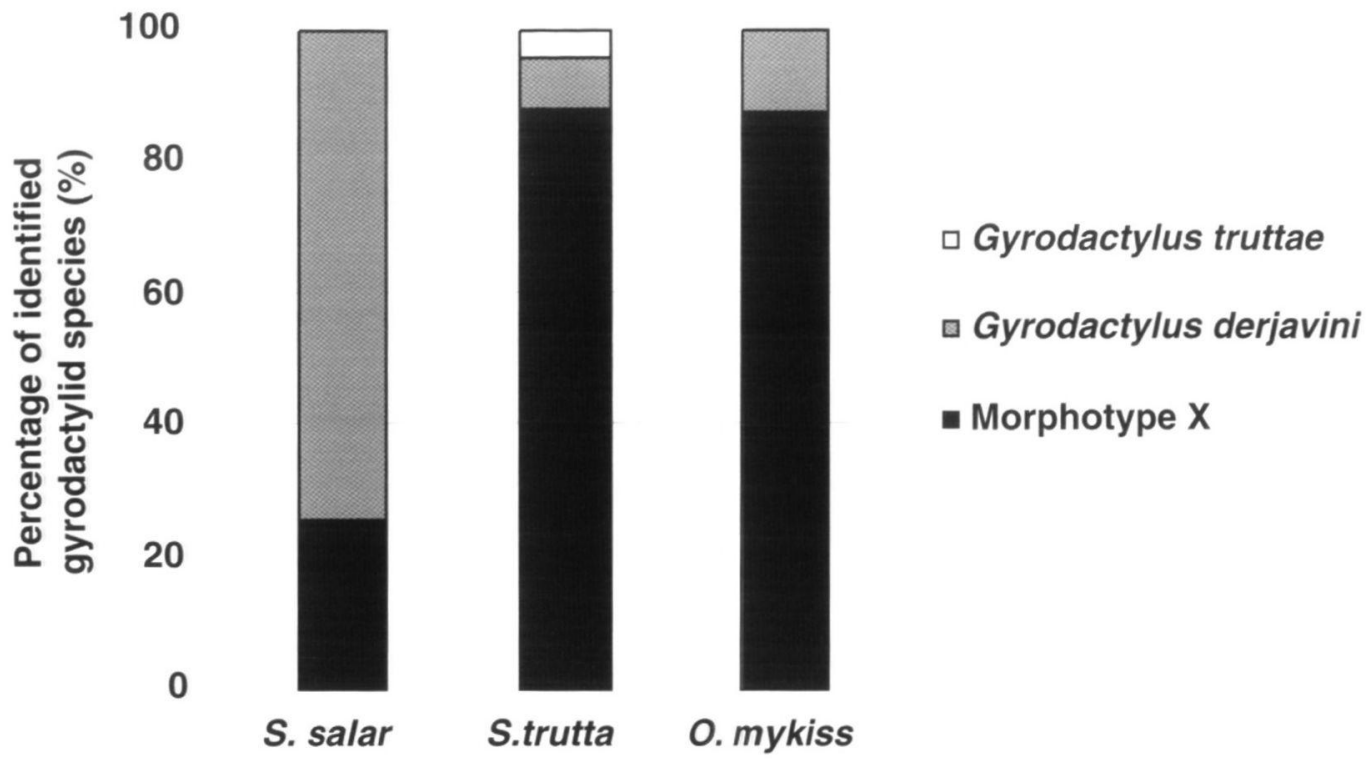

Host species

\section{Figure 9}

Proportions of the different gyrodactylid species among the three host species.

\section{Figure 9}

Proportions des différentes espèces de gyrodactyles parmi les trois espèces hôtes.

\section{Table IV}

Distribution of the different gyrodactylid species among the sampling sites of Brittany. G. d: G. derjavini, G. $t$ : G. truttae, G. X : morphotype X, G. s : G. salaris.

\section{Tableau IV}

Distribution des différentes espèces de gyrodactyles parmi les stations de Bretagne. G. $d:$ : G. derjavini, G. $t$ : G. truttae, G. X : morphotype X, G. $s$ : G. salaris.

\begin{tabular}{|c|c|c|c|c|c|}
\hline Sampling site & $\begin{array}{c}\text { Host } \\
\text { species }\end{array}$ & G. $d$ & G. $t$ & G. $X$ & G. $s$ \\
\hline \multirow{2}{*}{ Scorff } & S. salar & $=$ & $=$ & $=$ & $=$ \\
\hline & S. trutta & $=$ & $=$ & \pm & $=$ \\
\hline \multirow{2}{*}{ Aven } & S. salar & \pm & $=$ & $=$ & $=$ \\
\hline & S. trutta & \pm & $=$ & \pm & $=$ \\
\hline \multirow{2}{*}{ Elorn } & S. salar & \pm & $=$ & \pm & $=$ \\
\hline & S. trutta & $=$ & $=$ & \pm & $=$ \\
\hline \multirow{2}{*}{ Trieux } & S. salar & \pm & $=$ & \pm & $=$ \\
\hline & S. trutta & \pm & $=$ & \pm & $=$ \\
\hline \multirow{2}{*}{ Ellé } & S. salar & \pm & $=$ & $=$ & $=$ \\
\hline & S. trutta & \pm & \pm & \pm & $=$ \\
\hline \multirow{2}{*}{ Jet } & S. salar & \pm & $=$ & \pm & $=$ \\
\hline & S. trutta & \pm & $=$ & \pm & $=$ \\
\hline \multirow{2}{*}{ Léguer } & S. salar & \pm & $=$ & \pm & $=$ \\
\hline & S. trutta & $=$ & $=$ & \pm & $=$ \\
\hline
\end{tabular}


Table V

Distribution of the different gyrodactylid species among the sampling sites of Western Pyrénées. G. d: G. derjavini, G. $t: G$. truttae, G. X : morphotype X, G. $s$ : G. salaris.

\section{Tableau V}

Distribution des différentes espèces de gyrodactyles parmi les stations du bassin de l'Adour. G. $d$ : G. derjavini, G. $t$ : G. truttae, G. X : morphotype X, G. $s$ : G. salaris.

\begin{tabular}{|c|c|c|c|c|c|}
\hline Sampling site & $\begin{array}{c}\text { Host } \\
\text { species }\end{array}$ & G. $d$ & G. $t$ & G. $X$ & G. $s$ \\
\hline \multirow{2}{*}{$\begin{array}{c}\text { Nive } \\
\text { d'Arnéguy }\end{array}$} & S. salar & \pm & & $=$ & $=$ \\
\hline & S. trutta & $=$ & $=$ & \pm & $=$ \\
\hline \multirow{2}{*}{$\begin{array}{c}\text { Nive de } \\
\text { Béhérobie }\end{array}$} & S. salar & $=$ & $=$ & \pm & $=$ \\
\hline & S. trutta & \pm & $=$ & \pm & $=$ \\
\hline \multirow{2}{*}{ Saison 1} & S. salar & \pm & $=$ & $=$ & $=$ \\
\hline & S. trutta & $=$ & $=$ & $=$ & $=$ \\
\hline \multirow{2}{*}{ Gave d'Aspe } & S. salar & $=$ & $=$ & \pm & $=$ \\
\hline & S. trutta & $=$ & $=$ & \pm & $=$ \\
\hline \multirow{2}{*}{ Gave d'Ossau } & S. salar & \pm & $=$ & \pm & $=$ \\
\hline & S. trutta & \pm & \pm & \pm & $=$ \\
\hline \multirow{2}{*}{ Saison 2} & S. salar & \pm & $=$ & $=$ & $=$ \\
\hline & S. trutta & $=$ & \pm & \pm & $=$ \\
\hline \multirow{3}{*}{ Grande Nive } & S. salar & $=$ & $=$ & \pm & $=$ \\
\hline & S. trutta & \pm & $=$ & \pm & $=$ \\
\hline & O. mykiss & \pm & $=$ & \pm & $=$ \\
\hline
\end{tabular}

\section{Distribution of the gyrodactylid species in Brittany and Western Pyrénées}

Although the protocol was not designed for gyrodactylid communities study, a global analysis of the distribution of the 249 morphologically identified gyrodactylids among the three host species revealed the tentative following trends (see also Figure 9) : (1) Atlantic salmon parr are mainly parasitized by Gyrodactylus derjavini and less frequently by the morphotype $X ;(2)$ opposite proportions are observed on both brown and rainbow trout for which morphotype $X$ is the most frequent gyrodactylid species encountered; (3) G. truttae appears quite rare and restricted to brown trout.

The distribution of the different gyrodactylid species among the sampling sites is shown in Tables IV (Brittany) and V (Western Pyrénées). The morphotype $X$ and G. derjavini are widely distributed in the different sampled regions.

\section{DISCUSSION}

This work is, to our knowledge, the first study dealing with gyrodactylid infections of wild salmonids in France. Moreover, this is the first large scale exploitation of the molecular identification methods elaborated by CUNNINGHAM (1997).

Sampling method was planned following MALMBERG's “ Manual for investigating fish for Gyrodactylus " (1996). As mentioned by this author (personal communication), sampling constraints, electrofishing, ...may induce some bias in prevalence or parasites distribution among the host species. Nevertheless, these bias remain probably negligible due to the shortening of the different critical phases along the sampling process. 
The sampling period was chosen in accordance with literature data. In Norway, a few years after Gyrodactylus salaris introduction in a salmon population, prevalence remains close to $100 \%$ except in late winter and early spring (MO, 1992 ; JOHNSEN and JENSEN, 1992 ; APPLEBY and MO, 1997). Mean parasite intensity is maximum in the fall with between 400 to 1300 parasites per fish (APPLEBY and MO, 1997).

Reliability of measurements depends on the inherent problems in precision of drawings and light microscopy. Yet, the comparison of our results with those given in O.I.E. manual did not suffer from this relative lack of precision because the same methods were used in both works. Identification of gyrodactylids, when done following the O.I.E. procedure, actually relies more on sclerites morphology than on their size.

Actually, the range of variation of the characters measured on the sclerites of G. teuchis is enclosed within the total range reported for $G$. salaris (O.I.E., 1997 ; MO, $1991 \mathrm{a}, \mathrm{b}$ and $\mathrm{c}$ ).

The largest morphological differences between $G$. teuchis and $G$. salaris were observed in the shape of the marginal hook sickle. In $G$. salaris, regardless of the host species, the inner curve of the sickle encompasses an oval shape described by the long narrow form of the sickle tapering throughout its length whereas, in $G$. teuchis, the inner curve of the sickle is rounded approximatively as a circle portion. In G. salaris, the base of the sickle is shallow, the heel weakly pronounced and the toe is narrow, at the same level with the heel base when in $G$. teuchis, the heel is more globose, the toe is almost triangular and more angular in shape and its base forms a distinct curve (see Figure 6). As in $G$. derjavini, the junction between the sickle shaft and the toe, in $G$. teuchis, forms a marked angle (almost square), whereas this region is more rounded in $G$. salaris. In the latter species, the shaft of the sickle, long and slender, tapers to a point beyond the level of the toe but not to the extent observed in G. teuchis ; consequently, the shaft of G. teuchis appears longer, the sickle point more curved and the aperture of the sickle more closed.

The relative position of the indentation on the inner curve of the hamulus is situated in the lower third of the adjacent dorsal bar attachment point in G. salaris (SHINN, SOMMERVILLE and GIBSON, 1995). It differs from G. teuchis where the position of the indentation, marked by the ventral bar attachment point, is opposite the mid-point of the dorsal bar attachment point. Other morphological differences are presently being addressed.

In our work, we used ITS restriction fragment length polymorphism to discriminate between species of gyrodactylids (CUNNINGHAM, 1997). Intraspecific (or even intraindividual) variations in ITS region were reported for several parasite species like Schistosoma japonicum (VAN HERWERDEN, BLAIR and AGATSUMA, 1998), Paragonimus westermani (VAN HERWERDEN, BLAIR and AGATSUMA, 1999) or Echinococcus granulosus (BOWLES, BLAIR and McMANUS, 1995). Weather these variations also occur in gyrodactylids is still unknown. As little variations in a sequence may modify digestion patterns ; reliability of ITS RFLP in gyrodactylid species identification remains uncertain. Nevertheless, the data obtained in this study show a high degree of consistency. Furthermore, they were confirmed by those of an independent work performed elsewhere (CUNNINGHAM, personal communication).

Among the 535 salmonids examined in this work, any Gyrodactylus salaris was ever identified, nor by morphological methods performed on 249 randomly selected gyrodactylids, nor by molecular analysis of 92 other specimens. These consistent data lead us to assert that the Brittany and Western Pyrénées samples were free from G. salaris. 
Beside the total absence of Gyrodactylus salaris, a new original morphotype was observed on a large number of fish. The sclerites of this morphotype are close in shape and identical in size range for each of the 14 characters to those of $G$. salaris as mentioned in the O.I.E. "Diagnostic manual for aquatic animal disease ". Their morphology did not correspond to any known species. In association to this new morphotype, ITS digestion revealed an unexpected pattern on gyrodactylids picked from any salmonid species. Moreover, the V4 and ITS sequences attached to this new pattern demonstrated its genetic originality. Nor the ITS pattern, nor any of the two sequences were ever reported. This original morphological and genetic entity represents a new species which is named Gyrodactylus teuchis (CUNNINGHAM et al., in prep.).

This new species shares, among others, a large DNA sequence (around one hundred nucleotides) of $V 4$ region with $G$. salaris. This common DNA portion includes the target site (nucleotides 679 to 694 ; CUNNINGHAM et al., 1995) used in probe hybridization of $G$. salaris. Thus, discrimination between these two gyrodactylid species appears impossible when the species identification is performed with GsV4B probe hybridization. Therefore, we think that the identification of $G$. salaris in France, performed by JOHNSTON et al. (1996), results from such a confusion.

From the present knowledge of Gyrodactylus salaris biology, it is possible to draw the main features favouring the introduction and the maintenance of this parasite in a water basin or in a region : (1) macro-environmental conditions occurring in the water basin : water temperature is the most important factor conditioning the development of Gyrodactylus salaris populations in freshwater. Reproduction rate is positively correlated with temperature (JANSEN and BAKKE, 1991) like both prevalence and parasite intensity (MO, 1992 ; APPLEBY and MO, 1997) ; (2) frequent introductions of live receptive salmonids from infected areas (MALMBERG, 1993) or from different geographical origins favour the circulation of pathogens. Rainbow trout, the major farmed species in France and in many other European countries, has been proved to be an efficient vector in transmitting the parasite to new localities (MALMBERG, 1993 ; BAKKE, JANSEN and KENNEDY, 1991) ; (3) presence of receptive host species among which: Atlantic salmon, from the East Atlantic stock like Norwegian and Scottish salmon (BAKKE and MAC KENZIE, 1993), or from the Baltic stock (BAKKE, JANSEN and HANSEN, 1990) ; rainbow trout, which is capable of maintaining a parasite population for a long period (BAKKE, JANSEN and KENNEDY, $1991)$; brown trout, although this species does not represent a long term suitable host (JANSEN and BAKKE, 1995).

Brittany and Western Pyrénées are important rainbow trout producers with diversified stocking origins. They harbour the largest French populations of wild Atlantic salmon. At last the temperate waters of Brittany and, in a lesser extent, of Western Pyrénees (in which mean water temperature is higher than in Norway) represent good macro-environmental conditions for the parasite populations. Thus, the sampled regions both cumulate all the best conditions prevailing in France for Gyrodactylus salaris introduction, maintenance and development.

In the case of an effective presence of $G$. salaris in France for several years, one or both sampled regions should harbour the parasite. Then, the $G$. salaris prevalence would depend on the susceptibility of the basin native salmon strains. This susceptibility can be located between two extreme status : (1) susceptibility close to that of Norwegian or Scottish salmon (experimentally assessed by BAKKE and MAC KENZIE, 1993), who both belong to the East Atlantic stock, as French salmon are considered to belong. Then, in the fall, the prevalence on salmon parr should be close to $100 \%$ and parasite intensity should be quite high. Therefrom, the method used in this work could not have failed in G. salaris detection. (2) resistance to $G$. salaris, like in Baltic salmon stock (which is considered different from East Atlantic stock). To our knowledge, data about prevalence of $G$. salaris on wild Baltic salmon are insufficient to provide a basis for the estimation of a minimum prevalence in the 
case of resistant French Atlantic salmon. However, MALMBERG and MALMBERG (1993) investigated 15 Swedish rivers in the Baltic drainage region for gyrodactylids; $G$. salaris occured in three rivers and its prevalence on Atlantic salmon parr or smolts varied between 20 to $68 \%$. Besides, RINTAMAKI-KINNUNEN and VALTONEN (1996) studied the prevalence of $G$. salaris on farmed Atlantic salmon parr from the Baltic stock. The value situated between $8.8 \%$ and $17.7 \%$ on yearlings (age $1+$ ) and smolts but was much lower $(1.2 \%)$ among fingerlings (age $0+$ ).

According to CANNON and ROE in THRUSFIELD (1995), the probability (p) of failure to detect any parasitized fish in a sample (size $=n$ ) from an infinite population decreases with increasing levels of prevalence $(P)$ :

- for $P<5 \%$, if $n=100$, then $p<0.006$. Thus, the absence of $G$. salaris in the samples from Brittany ( $n=192$ Atlantic salmon) and from Western Pyrénées ( $n=115$ Atlantic salmon) means that this species is absent from the sampled water basins in Brittany and from the Adour basin with, at least $99.4 \%$ level of confidence.

- If the total sample size (535 wild and farmed receptive salmonids from both areas) is taken into account, then, $G$. salaris can be considered absent from these two regions at a $99.3 \%$ level of confidence for a prevalence superior to $1 \%$ or with a $99.9 \%$ level of confidence for a prevalence above $2 \%$.

The absence of $G$. salaris in these regions and the highly probable confusion of $G$. salaris with $G$. teuchis by JOHNSTON et al. (1996) makes dubious the actual presence of $G$. salaris in France.

Gyrodactylids are common parasites on salmonids. Their presence in all the sampling sites is not surprising. Their prevalence on wild fish in Brittany is significantly higher than in Western Pyrénées. Western Pyrénées waters remain cold during several months in winter and spring, because of snow thawing, while water temperature in Brittany remains relatively high because of the Gulf stream effects. These differences in respective temperature patterns may explain the respective levels of prevalence. MO (1992), MALMBERG (1993) and APPLEBY and MO (1997) related a positive correlation between temperature and both prevalence and intensity of Gyrodactylus salaris on Atlantic salmon parrs.

Prevalence of gyrodactylids on wild brown trout was around twice that observed on Atlantic salmon. This significant difference is probably related to the respective receptivities of each host species to each gyrodactylid species. This result was strongly amplified in restocking farms, where the prevalence on brown trout was significantly higher than that on wild trout. This is consistent with MALMBERG (1993) who considers that the higher fish density in the tanks of a farm favours the development of gyrodactylid populations. The prevalence level is also submitted to the influence of external treatments. It must be noted that, in our work, fish farmers were asked not to treat for several days before sampling which may explain the $100 \%$ prevalence occuring in farmed brown trout.

A despite a higher density in farming conditions, an opposite pattern was observed on Atlantic salmon : wild fish were significantly more parasitized than farmed ones. Several factors could be involved in this observation:(1) the main environmental difference between wild and farmed salmon is the absence of any cohabitation between the latter and other fish species ; (2) Atlantic salmon farming for river stocking is considered as more delicate than brown trout farming ; consequently, salmon is the subject of specific care, as, lower density (compared to that of brown trout) and more frequent antiparasitic treatments. 
Because of the opposite proportions of Gyrodactylus teuchis between brown trout and Atlantic salmon, in both Western Pyrénées and Brittany, the adaptation of $G$. teuchis to brown trout appeared better than to Atlantic salmon. Moreover, the latter is mostly parasitized by $G$. derjavini which is yet considered more specific of brown trout (MALMBERG, 1993). Nevertheless, occurrence of $G$. derjavini on salmon parrs is a common feature in other countries (BAKKE et al., 1992 ; MALMBERG and MALMBERG, 1993 ; SHINN, SOMMERVILLE and GIBSON, 1995).

\section{CONCLUSIONS}

The first important result of this study is the absence of Gyrodactylus salaris in the rivers of Brittany and Western Pyrénées. The second is the occurrence of a new species belonging to the Gyrodactylus genus : Gyrodactylus teuchis. This parasite was probably confused with Gyrodactylus salaris by JOHNSTON et al. (1996) because of their close morphology and some genetic similarities.

The absence of $G$. salaris in the two sampled regions implies its possible absence from the whole French territory. Further investigations in other areas harbouring Atlantic salmon should be performed. Because of the particular status of rainbow trout (MALMBERG, 1993), this survey should even be extended to rainbow trout farms.

If the absence of this parasite was confirmed, then French health status towards G. salaris should be soon re-examined. The erroneous identification of $G$. salaris due to the confusion with $G$. teuchis may also have occurred in other European countries. A serious investigation in whole continental Europe should be carried out to clarify the actual infected area which currently remains unknown.

Gyrodactylus teuchis is widely distributed in the sampled regions and has been found to parasitize the three sampled salmonids. Most biological characteristics of this new species, especially its specificity and pathogenicity, are by now unknown and deserve to be investigated.

This paper is an opportunity to highlight the complementarity of two identification methods : the classical morphological examination and the recent molecular analysis. Nevertheless, some difficulties encountered in our work along the identification process, revealed some shortcomings in each method. This paper is an occasion to highlight the interest of an improvement in both methods.

\section{ACKNOWLEDGMENTS}

Grateful thanks are addressed to the " MINISTERE DE L'ENVIRONNEMENT ET DE L'AMÉNAGEMENT DU TERRITOIRE " and “CONSEIL SUPÉRIEUR DE LA $P \hat{E} C H E$ " for their financial support. The authors whish to greatly thank Dr. C. $O$. CUNNINGHAM for her help and for the useful plasmids providing. Prof. G. MALMBERG is respectfully thanked for his warmful encouragements and APG supplying. Special thanks to the "Délégations Régionales du CSP " from Pau and Rennes for their warmful help. Sincere thanks to the staff of "Brigade Mobile d'Intervention du CSP - Bretagne ", to the famous F. ROQUEFEUIL from " CSP Pau " and to the numerous « gardes-pêche fédéraux " for their organisation and their efficient help in the sampling. Grateful greetings to A. BASK-LE BOUDEC and D. BARRACOU for their help with MAPINFO. C. ARNAULD, AFSSA PLOUFRAGAN is gratefully thanked for sequencing. Y. RUSQUET is particularly thanked for his helpful participation in fish sampling. 


\section{REFERENCES}

APPLEBY C., MO T.A., 1997. Population dynamics of Gyrodactylus salaris (Monogenea) infecting Atlantic salmon, Salmo salar, parr in the River Batnfjordselva (Norway). J. Parasitol., 83 (1), 23-30.

BAKKE T. A., MAC KENZIE K., 1993. Comparative susceptibility of native Scottish and Norwegian stocks of Atlantic salmon, Salmo salar L., to Gyrodactylus salaris Malmberg : laboratory experiments. Fish. Res., 17, 69-85.

BAKKE T. A., JANSEN P. A., HANSEN L. P., 1990. Differences in the host resistance of Atlantic salmon Salmo salar L., stocks to the monogenean Gyrodactylus salaris Malmberg, 1957. J. Fish Biol., 37, 577-587.

BAKKE T. A., JANSEN P. A., KENNEDY C. R., 1991. The host specifcity of Gyrodactylus salaris Malmberg (Platyhelminthes, Monogenea) : susceptibility of Oncorhynchus mykiss (Walbaum) under experimental conditions. J. Fish Biol., 39, 45-57.

BAKKE T. A., HARRIS P. D., JANSEN P .A., HANSEN L. P., 1992. Host specificity and dispersal strategy in gyrodactylid monogeneans, with particular reference to Gyrodactylus salaris (Platyhelminthes, Monogenea). Dis. Aquat. Organ., 1992, 63-74.

BOWLES J., BLAIR D., MCMANUS., 1995. A molecular phylogeny of the genus Echinococcus. Parasitology, 110, 317-328.

CUNNINGHAM C.O., 1997. Species variation within the internal transcribed spacer (ITS) region of Gyrodactylus (Monogenea : gyrodactylidae) ribosomal RNA genes. J. Parasitol, 83 (2), 215-219.

CUNNINGHAM C.O., Mc GILLIVRAY D.M., Mc KENZIE K., MELVIN W.T., 1995. Identification of Gyrodactylus (Monogenea) species parasitizing salmonid fish using DNA probes. J. Fish Dis., 18, 539-544.

ERGENS R., 1981. Variability of hard parts of opisthaptor in Gyrodactylus truttae Gläser, 1974 (Gyrodactylidae: Monogenea). Folia Parasit., 28, 37-42.

ERGENS R., 1992a. Redescription of Gyrodactylus truttae Gläser, 1974 (Monogenea : Gyrodactylidae) from Salmo trutta m. fario L. (Clupeiformes : Salmonidae). Folia Parasit., 39, 201-206.

ERGENS R., 1992b. Gyrodactylus bohemicus sp. n. (Monogenea : Gyrodactylidae) from Oncorhynchus mykiss (Walbaum) and Salvelinus fontinalis (Mitchill) (Clupeiformes: Salmonidae) in Czeckoslovakia. Folia Parasit., 39, 391-394.

JANSEN P.A., BAKKE T.A., 1991. Temperature-dependent reproduction and survival of Gyrodactylus salaris Malmberg, 1957 (Platyhelminthes : Monogenea) on Atlantic salmon (Salmo salar L.). Parasitology, 102 (1), 105-112.

JANSEN P.A., BAKKE T.A., 1995. Susceptibility of brown trout to Gyrodactylus salaris (Monogenea) under experimental conditions. J. Fish Biol., 46, 415-422.

JOHNSEN B.O., JENSEN A.J., 1991. The Gyrodactylus story in Norway. Aquaculture, 98, 289-302.

JOHNSEN B.O., JENSEN A.J., 1992. Infection of Atlantic salmon, Salmo salar L., by Gyrodactylus salaris, Malmberg, 1957, in the River Lakselva, Misvær in northern Norway. J. Fish Biol., 40, 433-444.

JOHNSTON C., MAC KENZIE K., CUNNINGHAM C.O., EIRAS J.C., BRUNO D.W., 1996. Occurrence of Gyrodactylus salaris Malmberg, 1957, in Portugal. Bull. Eur. Ass. Fish Pathol., 16 (3), 89-91.

MALMBERG G., 1970. The excretoty systems and the marginal hooks as a basis for the systematics of Gyrodactylus. Ark. Zool., 23, 1-237.

MALMBERG G., 1993. Gyrodactylidae et gyrodactylose des Salmonidae. Bull. Fr. Pêche Piscic., 328, 5-46. 
MALMBERG G., MALMBERG M., 1993. Species of Gyrodactylus (Plathyhelminthes, Monogenea) on salmonids in Sweden. Fish Res., 17, 59-68.

MARGOLIS L., ESCH G.W., HOLMES J.C., KURIS A.M., SCHAD G.A., 1982. The use of ecological terms in parasitology. J. Parasitol., 68, 131-133.

MO T.A., 1991a. Seasonal variations of opisthaptoral hard parts of Gyrodactylus salaris Malmberg, 1957 (Monogenea : Gyrodactylidae) on parr of Atlantic salmon Salmo salar L. in the River Batnfjordselva, Norway. Syst. Parasitol., 19, 231-240.

MO T.A., 1991b. Seasonal variations of opisthaptoral hard parts of Gyrodactylus salaris Malmberg, 1957 (Monogenea : Gyrodactylidae) on rainbow trout Oncorhynchus mykiss (Walbaum, 1792) in a fish farm, with comments on the spreading of the parasite in south-eastern Norway. Syst. Parasitol, 20, 1-9.

MO T.A., 1991c. Seasonal variations of opisthaptoral hard parts of Gyrodactylus salaris Malmberg, 1957 (Monogenea : Gyrodactylidae) on parr of Atlantic salmon Salmo salar L. in laboratory experiments. Syst. Parasitol., 20, 11-19.

MO T.A., 1992. Seasonal variations in the prevalence and infestation intensity of Gyrodactylus salaris Malmberg, 1957 (Monogenea : Gyrodactylidae) on Atlantic salmon, Salmo salar L., in the River Batnfjordselva, Norway. J. Fish Biol., 41, 697-707.

OFFICE INTERNATIONAL DES EPIZOOTIES, 1997. Diagnostic manual for aquatic animal diseases. OIE Edition, Paris.

PROST M., 1991. Fish Monogenea of Poland. IX. Two species of Gyrodactylus from Salmonidae. Acta Parasit. Pol., 36 (3), 109-114.

RINTIMAKI-KINUNEN P., VALTONEN E.T., 1996. Finnish salmon resistant to Gyrodactylus salaris : a long term study at fish farms. Int. J. Parasitol., 26 (7), 723-732.

SHINN A.P., SOMMERVILLE C., GIBSON D.I., 1995. Distribution and characterization of species of Gyrodactylus Nordmann, 1832 (Monogenea) parasitising salmonids in the UK, and their discrimination from Gyrodactylus salaris Malmberg, 1957. J. Nat. Hist., $29,1383-1402$.

THRUSFIELD M., 1995. Veterinary epidemiology. Blackwell Science, Oxford, 483 p.

VAN HERWERDEN L., BLAIR D., AGATSUMA T., 1998. Intra- and interindividual variations in nuclear ribosomal tanscribed spacer 1 of the Schistosoma japonicum species complex. Parasitology., 116, 311-317.

VAN HERWERDEN L., BLAIR D., AGATSUMA T., 1999. Intra- and interindividual variations in ITS1 of Paragonimus westermani (Trematoda : Digenea) and related species : implications for phylogenetic studies. Mol. Phylogenet. Evol., 12, 67-73. 